\title{
Obstacles to Women's Right against Domestic Violence in Nigeria
}

Ujah Marian Ofunu $^{1 *}$, Shaba Sampson ${ }^{2}$

\author{
${ }^{1}(\mathrm{Ph} . \mathrm{D})$, Lecturer, Department of Commercial and Industrial Law, Kogi State University Anyigba, Kogi State Nigeria \\ ${ }^{2}$ (Ph.D), Lecturer, Department of Public Law, Federal University Oye-Ekiti, Ekiti State Nigeria
}

\author{
DOI: $10.36348 /$ sijlcj.2021.v04i04.001 $\quad$ | Received: 27.02.2021 | Accepted: 02.04.2021 | Published: 13.04 .2021 \\ *Corresponding author: Ujah Marian Ofunu
}

\section{Abstract}

This paper examines obstacles to the existing laws and legislation for the protection of the Rights of Women against Domestic Violence in Nigeria. Domestic violence covers various aspects of violence and harassment to which women are subjected to in Nigeria. Challenges and impediments to the enforcement and implementation of instruments that provides against domestic violence on women is the focus of this paper. It found that the lack of institutional bodies to monitor and regulate the enforcement of extant laws in this regard coupled with socio-cultural norms and traditional values together impede their implementation. In addition, factors such as culture, illiteracy, economic, legal and political, have been identified as fundamentally affecting the efficacy of laws bothering on the rights of women. The paper recommends that existing laws such as the Violence against Persons (Prohibition) and Other Related Matters Act, 2015 which is a federal legislation and other laws that are against traditional practices like domestic violence against women should be reviewed in line with international standards. In addition, there should be in place a body to monitor the implementation of these laws.

Keywords: Domestic, Challenges, Impediments, Rights, Women.

Copyright (C) 2021 The Author(s): This is an open-access article distributed under the terms of the Creative Commons Attribution 4.0 International License (CC BY-NC 4.0) which permits unrestricted use, distribution, and reproduction in any medium for non-commercial use provided the original author and source are credited.

\section{INTRODUCTION}

Human beings by nature possess certain basic and inalienable rights which are commonly known as human rights [1]. Certain groups of human beings, either by their nature or because of deep-rooted customs are weak and vulnerable. Women are found to be prominent in the categories of the vulnerable and their rights are frequently violated as a result with impunity by their male counterparts through domestic violence. Domestic violence is a global phenomenon and common place and has since assumed a new dimension [ 2 ]. Considering its rampancy and wide spread occurrence it becomes clear that the violence syndrome is prevalent in all societies and cultures no matter their levels of civilization [3]. True to its fundamental ideals,

${ }^{1} \mathrm{H} \mathrm{O}$ Agarwal,.International Law and Human Rights (17 ${ }^{\text {th }}$ edn. Central Law Publications 2010) 730.

2 O O Azubike, Personal Liberty and Domestic Violence: Any Legal Response in Nigeria' [2010] (6)

(2) University of Ilorin Law Journal 20.

${ }^{3} \mathrm{R}$ Coomaraswany, 'Preliminary report submitted by the special Rapporteur on Violence against Women, It's the United Nations as a global body has contributed in no small measure in spreading the message of Human Rights. Several Conventions have been made under the auspices of the United Nations with the aim to protect the rights of women [4].

Causes and Consequences, In Accordance with Commission on Human Rights Resolution 1994/45; 4-9 available at $<$ www.undehr.ch/hurridoca nastiest frame $75 \quad$ ccfd7970712d08d25670b005c9c7d7open document.> Accessed on November 152019.

${ }^{4}$ see for example Convention on the Elimination of All Forms of Discrimination Against Women(CEDAW) adopted in 1979, United Nations Convention on the Rights of Women,1986, Universal Declaration of Human Rights (1948), Optional Protocol to the Convention on the Elimination of All Forms of Discrimination Against Women (1999), The Declarationon on Elimination of Violence against Women(1993), Inter-American Convention on the Prevention, Punishment and Eradication of Violence against Women(1994), the Convention against Torture and Other Cruelty, Inhuman or Degrading Treatment or Punishment (1984), Convention on the Political Rights 
Ujah Marian Ofunu \& Shaba Sampson., Sch Int J Law Crime Justice, Apr, 2021; 4(4): 189-197

In addition to these Conventions, Conferences have been held under the aegis of the United Nations such as the International Women Conference in Mexico City [5], Copenhagen [6], Nairobi [7] and Beijing being the Fourth World Conference on women commonly known as Beijing Conference, 1995 [ 8 ]. These Conferences and Conventions have greatly enhanced international awareness on the concerns of women and have provided the link between the National Women Movements and the International Community. Furthermore, there are other human rights instruments which have been adopted under the auspices of the United Nations for the protection of vulnerable groups such as women [9].

The United Nations affirmed in its Charter the promotion, protection and respect for human rights and fundamental freedoms for all persons without discrimination as to race, religion or sex. In December 1948 the Universal Declaration of Human Rights ("UDHR") was adopted. It also affirmed the equality of all human beings and the equal enjoyment of all human rights by all with a clear statement on nondiscrimination on the basis of sex [10]. Subsequent human rights instruments reaffirm this equality and the equal entitlement to enjoyment of human rights. It is therefore, crystal that all women are entitled to the enjoyment of these rights as entrenched in the instruments hence, gender, custom and law can no longer be used as tools to deny them these rights [11].

Similar provisions can be found in regional human rights instruments. For instance, the European Human Rights System has put in place measures for the protection of the rights of vulnerable groups [12]. In the

of Women(1952) and African Charter on Human and Peoples Rights/Protocol on the Rights of Women(2003).

${ }^{5} 1975$.

${ }^{6} 1980$.

${ }^{7} 1985$.

${ }^{8} 1995\left(4^{\text {th }}-15^{\text {th }}\right.$ September, 1995).

9 These instruments include Convention on the Elimination of all Forms of Discrimination Against Women adopted by the United Nations, G.A. Res. 34/180 December 1979. It came into force on September 3, 1981; the Optional Protocol to the Convention on the Elimination of Discrimination Against Women, UN G. A. Res. A. /54/A October,1999. It came into force in December 22,2000. ${ }^{10}$ UDHR, 1948 articles 22-27.

${ }^{11}$ A Ibidapo-Obe Policing Response to Vulnerable Group: A Review of Strategies for Tackling Crime aginst Women and Children, O Oluduro,et als,(eds.) Trends in Nigerian Law: Essays in Honor of Oba DVF Olateru Olagbege III, Olowo of Owo Kingdom (Constellation Nig. Publishers 2007) 84.

${ }^{12} \mathrm{~T}$ F Yerima, 'Human Rights Protection of Women in Africa: Journey so Far' [2009] (1) (3) Akungba Law
Inter- American System, similar measures are in place for the protection and promotion of human rights [13]. Also, the Africa Human Rights System has given particular attention to women, children and refugees; especially the Protocol to the African Charter on Human and Peoples' Rights on the Rights of Women in Africa [14]. Even before this Protocol, the African Charter [15] itself had provided in articles 2, 3, 4 and 5 for the protection of the rights and dignity of all persons, women inclusive, and their right to equality before the law. It provides that every individual shall be entitled to the rights and freedoms recognised and guaranteed in the present Charter without distinction of any kind on ground of race, ethnic group, colour, sex or other statuses [16].

In the same vein the Convention Governing the Specific Aspects of Refugees in Africa [17], as well as the African Charter on the Rights and Welfare of the Child have similar provisions on the protection of women rights. It is pertinent to note that since African countries are parties to different international human rights instruments that seek to protect the rights of vulnerable groups, women inclusive, a high level of performance in this regard is expected from them.

Under Chapter II of the Constitution of the Federal Republic of Nigeria 1999 (as mended) [18], section 13 makes it obligatory for all organs of government and all authorities and persons exercising legislative, executive or judicial powers to conform, to observe and apply the provisions of Chapter II of the constitution. Section 15(2) prohibits discrimination by the State on grounds of place of origin, sex, religion, status, ethnic or linguistic association or ties. The

Journal 177. For example: Convention for the Protection of National Minorities signed by members of Council of Europe on Feb 1, 1995 at Strasbourg which came into force on Feb.1996; the Report on the Conference on Security and Co-operation in Europe (CSCE); the Meeting of Experts on National Minority, Geneva adopted on july19,1991 at Geneva.

${ }^{13}$ For example, the Inter-American Convention on the Protection, Punishment and Eradication of Violence against Women, adopted at the 24 Regular Session of the G. A. of the Organization of American States (OAS) which came into force on March 5, 1995.

${ }^{14}$ Protocol to the African Charter on Human and Peoples' Rights on the Rights of Women in Africa, adopted by the $2^{\text {nd }}$ Session of the G.A, Maputo on July 11, 2003.

${ }^{15}$ African Charter, articles 2 and 5.

${ }^{16}$ Ibid, article 5 .

17 Convention Governing the specific Aspect of Refugees in Africa, adopted by the African Heads of States and Governments in Addis Ababa on September 10, 1969 and entered into force on June 20, 1974.

${ }^{18}$ Herein referred to as the Constitution. 
Ujah Marian Ofunu \& Shaba Sampson., Sch Int J Law Crime Justice, Apr, 2021; 4(4): 189-197

Constitution further provides [19] for equal rights, equal obligations and equal opportunities for citizens before the Law as well as the sanctity of the human person and maintenance of human dignity. It also directs the States to protect, preserve and promote the Nigerian culture which enhances human dignity and is consistent with the fundamental objectives as provided in Chapter II of the Nigerian Constitution [20].

Chapter $1 \mathrm{~V}$ of the Nigerian Constitution [21] contains elaborate provisions guaranteeing the fundamental rights of citizens. Section 42(1)(a) makes specific provision to the effect that:

A citizen of Nigeria of a particular community, ethnic group, place of origin, sex, religion or political opinion shall not, by reason only that he is such a person be subjected ... to disabilities or restrictions ....

\section{PERSPECTIVES ON DOMESTIC VIOLENCE}

Domestic violence entails physical or emotional harm. It includes/extends to threat or indecent assault, undue curtailment of freedom, and personal or economic intimidation. In fact, the list includes any expression that demeans a person's dignity, any physical assaults, beating or strangulation, jabs with sharp or blunt objects, slaps, kicks and sexual abuse of any kind, including inordinate demand and/or refusal are manifestation of violence within the household or family [22].

For better understanding of the term 'domestic violence' against women, the United Nations General Declaration on the Elimination of Violence against Women, via Resolution 48/1104 of December $20^{\text {th }} 1993$

${ }^{19}$ Section $17(2)(a)(b)$.
${ }^{20}$ Section 21(a).
${ }^{21}$ Sections 33-44 of the Constitution of the Federal Republic of Nigeria 1999 (as amended) provides for the following rights: right to life; right to dignity of human person; right to personal liberty; right to fair hearing; right to private and family life; right to freedom of thought, conscience and religion; right to freedom of expression; right to peaceful assembly and association; right to freedom of movement. Specifically, the Constitution provides that every individual is entitled to respect for the dignity of his human person and accordingly, no person shall be subjected to torture or to inhuman or degrading treatment.

${ }^{22} \mathrm{R}$ Howard, 'Women's Right in English Speaking SubSaharan' in C Welch and R Meltzer Jr (eds.) Human Rights and Development in Africa (Pearson Education Inc.1984) 59. See article 1 of the Protocol to the African Charter on Human and Peoples' Rights on the Rights of Women in Africa; UN General Assembly Resolution 48: 1/104, 'Declaration on the Elimination of Violence against Women', December 20, 1993.
[23] defines violence against women broadly in its article 1 to mean:

Any act of gender -based violence that result in or is likely to result in physical, sexual or psychological harm, or suffering of women, including threats of such acts, coercion or arbitrary deprivation of liberty, whether in public or private life.

Women rights activists advocate legal and social equality with men for the fact that women rights are human rights. These rights include the right to live free from violence and discrimination; to enjoy the highest attainable standard of physical and mental health; to be educated; to own property; to vote and to earn an equal wage among others [24]. There are however, a myriad of factors that hinder or impede the realisation or the enforcement or implementation of the instruments in place for the protection of women against domestic violence [25].

Owing to lack of commitment the realization of these rights is more or less a utopian especially in a society as Nigeria where disregard to Constitutional authority and disobedience to court orders even by government appears normal. This is worrisome and even compounded by the erroneous believe by men that discussion on women rights tantamounts to slowing the development of the country [26].

As pointed out earlier, Nigeria is signatory to many international human rights instruments [27] and has laudable and inspiring constitutional provisions for their workability/implementation [28]. Notwithstanding,

\footnotetext{
${ }^{23}$ The United Nations in 1993 at the General Assembly adopted a Declaration on the Elimination of Violence against Women via Resolution 48/1104 of December $20^{\text {th }}, 1993$.

${ }^{24}$ Agarwal, (n1). See O Aloy, 'Domestic Violence and the Law' [2010] (1) (1) Nigeria Journal of Gender Studies 8.

${ }_{25}$ These include gender-based violence, harmful traditional or cultural practices, exclusion of women from peace tables or state laws.

${ }^{26}$ These views were also expressed in G J Steiner and P Alston, International Human Rights in Context, Politics, Morals (Clarendon Press, 1999) 887 where the problem of enforcement of laws against domestic violence is succinctly analyzed.

${ }^{27}$ Such as the Universal Declaration of Human Rights 1948, the International Covenant on Civil and Political Rights 1966, the International Covenant on Economic, Social and Cultural Rights 1966 and the African Charter on Human and Peoples Rights 1981.

${ }^{28}$ Two Chapters of the 1999 constitution (Chapters 2 and 4) are exclusively dedicated to human rights. In addition, Nigeria has established ostensibly strong institutional infrastructure for the human rights
} 
Ujah Marian Ofunu \& Shaba Sampson., Sch Int J Law Crime Justice, Apr, 2021; 4(4): 189-197

there has been varying degrees of violations even by government of these basic rights and fundamental freedoms [29].

Impediments to the full realization of the rights of women in Nigeria are multidimensional and include; constitutional provisions, cultural, political, legal, etcetera reasons. Some constitutional provisions on women rights are rather lame and lack the potency to really enliven and galvanise women rights. For instance, there are numerous derogation clauses which are not only too wide and wild, but ill-defined and nebulous. Similarly, the socio-political environment in Nigeria is in several ways not conducive to any meaningful human rights regime. Often, government exhibits autocratic tendencies and in the process have sadly erected a culture of impunity by regular disobedience of court judgments and orders. The result is that victims of domestic violence are left without commensurate legal remedy.

Impediments against the realization of women rights are multifaceted and intertwined. They however, differ among countries depending on their peculiarities. In Nigeria, domestic violence against women is encouraged, accentuated and sustained by several factors, such as culture, economic, legal, illiteracy, and lack of political will on the part of government.

\section{THE NIGERIAN CONSTITUTION AND HUMAN RIGHTS TREATIES}

Section 12 of the 1999 Constitution of the Federal Republic of Nigeria relates to treaties and how they can be implemented. Since international human rights instruments are essentially multi-lateral treaties, a careful perusal of the provisions of section 12 becomes relevant. The section provides that:

i. No treaty between the Federation and any other country shall have force of law except to the extent to which any such treaty has been enacted into by the National Assembly.

ii. The National Assembly may make laws for the Federation or any part there of with respect to matters not included in the Exclusive

promotion and protection. Apart from the judicial organ, Nigeria has extrajudicial bodies for human rights promotion and protection. These include the National Human Rights Commission and the Public Complaints Commission.

${ }^{29}$ For recent examples of human Rights violations in Nigeria, particularly domestic violence cases, see the latest Human Rights Report submitted by the U S. Department of State to the U.S Congress, available at < htt://www.state.gov/documents/organization/160138.pd f $>$ accessed on 12/9/2019, and also A Olayinka, 'On Death Row' TELL MAGAZINE (Nigeria) October 20, 202022.
Legislative List for the purpose of implementing a treaty.

The implication of the provisions of section 12 of the Constitution is that human rights treaties entered into by Nigeria will not become binding until same have been legislated upon and passed into law by the National Assembly. In General Sanni Abacha v. Gani Fawehinmi [30], the Supreme Court after considering section 12(1) of the 1979 Constitution (now) section 12(1) of the 1999 Constitution held inter alia:

... an international treaty entered into by the government of Nigeria does not become ipso facto binding until enacted into law by the National Assembly and before its enactment, an international treaty has no force of law as to make its provisions actionable in Nigeria law courts [31].

The apex Court further held that, "unincorporated treaties cannot change any aspect of Nigerian law even though Nigeria is a party to those treaties"' but that they may however indirectly affect the rightful expectation by the citizens that government acts affecting them would observe the terms of the unincorporated treaties.

\section{FACTORS THAT ENCOURAGE DOMESTIC VIOLENCE}

Some of the factors that hinders the enforcement of the right of women against domestic violence includes; gender-specific socialization, cultural definition of appropriate sex roles, expectation of roles within relationship, believe in the inherent superiority of males, values that give men proprietary rights over women and girls. Notion of the family as private affair and under the male control; customs of marriage (such as bride-price/dowry), and acceptability of violence as a means of resolving conflicts are also impediments.

In the segment following these impediments have been identified as being cultural, economic, legal, political, and illiteracy factors and discussed.

\section{Culture}

In the traditional Nigerian home, which is made up of patriarchal communities, superiority is so entrenched that even the land, is never referred to as "our motherland" but as our fatherland. [32] The

\footnotetext{
${ }^{30}$ (2000) [6] NWLR228 (Nigeria). The combined effect of the above provision also entails that international treaties can be enforced if the corresponding law has been enacted by Parliament.

${ }^{31}$ The enactment of international treaties into domestic law is what is referred to as the concept of domestication or transformation of treaties.

${ }^{32}$ See the Nigeria National Anthem which says "to serve our fatherland" with love and strength and faith... the
} 
Ujah Marian Ofunu \& Shaba Sampson., Sch Int J Law Crime Justice, Apr, 2021; 4(4): 189-197

women have no right to land,[33] in cultures where the wife is more or less the property of the husband who has 'paid' a price and obtained all entitlements to "have and keep" her under his might.[34]

Also, girls are socialized from birth to fetch and carry water or firewood and look forward to becoming humble brides and nothing more. Their male counterparts on the other hand are raised with the notion that women are made to serve them. The Nigerian psyche is further confused by the fact that Nigerians are deeply religious people. Typically, the main religions embraced by Nigerians are also products of a male-dominated history and have made the woman sheepish and unassertive.

The various Human Rights Conventions, to which Nigeria is signatory, as well as the Constitution of the Federal Republic of Nigeria, recognize equality of the sexes in their anti-discriminatory provisions [35] and abhor such gender-specific socialization that looks at the woman as a Second-Class citizen. A lot of violence inflicted in the domestic setting is justified as correction for disobedience or as a means of instructions for the desirable mode of conduct. It shows a society of men that take pleasure in unleashing violence on the women folk as a corrective measure. Even in the Bible [36], women were not counted in recounting the four and five thousand crowds that were fed by Jesus Christ with five loaves of bread and two fish.

The social context of violence against women in Nigeria is relatable to the traditional African

labour of our heroes past shall never be in vain.... Peradventure one raises the fact that there were also heroines in the past, one would quickly be referred to the Interpretation Act which states that "he" as used in our laws includes 'she' for all times.

${ }^{33}$ It can be argued that neither has the man seen his land right as vested in the Governor to be held in trust for the people under the land use Act of 1978. Though, there are on-going reforms at the moment, which one hopes will be adequately give clear rights to women, especially regarding traditional ownership, and in circumstances of widowhood.

${ }^{34}$ S C Ifemeje, 'Gender Base Domestic Violence in Nigeria: A Socio-Legal Perspective' [2012] Indian Journal of Gender Studies, 138-148.

${ }^{35}$ See the African Charter on Human and Peoples' Rights 1981, as well as its Protocols; see also Chapter IV of the Constitution of the Federal Republic of Nigeria, section 42 clearly states that no one is to suffer discrimination on account of sex, age, ethnic group or religion.

${ }^{36}$ The Gospel of Mathew Chapter 14 verse 21 and Mathew Chapter 27 verse 55. Holy Bible, New Living translation (Tyndale House Publishers, Inc. 2001) 597. patriarchal society that defines the gender power structure. For instance, upon marriage a woman surrenders all to her husband, excluding sexual rights and obedience. This invariably gives her husband the liberty to violate and batter her if he feels that she has not adequately fulfilled her obligations or for any other reasons. Where the socio-cultural factor of domestic violence is largely dependent on the gender power relation, the men are always right, and always win in any case against their wives. Surprisingly, it is mostly the female relatives of the man that are usually the first to accuse the woman and find her guilty irrespective of obvious signs of physical violence [37].

Under cultural correctness, a deluge of violence is often shielded and overlooked. Report of NGOs [38] working on women rights are replete with incidences of rape, assault and sometimes deaths resulting from such violence. A lot of rape, incest and assault are glossed over as family secrets that should not be aired so as to protect family name and esteem. To worsen the situation, the assaulted women are treated as perpetrators rather than victims and are stigmatized for life. Usually, the community would rather apportion blames to the victim citing modes of dressing, talkativeness or loose morals as exculpatory reasons for the crime [39]. Religion [40] has also become part of the cultural mix helping to justify female oppression. A plethora of verses of both the Holy Bible and the Holy Qur'an clearly portrays the woman as second thought in creation. This has sadly reconfigured the psyche of women and they are made to uphold this world view as correct though.

No doubt, "religion seems to still hold a firm grip on moral values relating to power relation between the wife and her husband" [41]. Consequently, women who are very religious are most likely to hold as strong and rigid the fundamentalists' type of belief that may

\footnotetext{
${ }^{37}$ A K Oyediran, and U C Isiugo-Abanihi, 'Perspective of Nigeria Women on Domestic Violence: Evidence from 2003 Nigeria Demographic and Health Survey’. A Publication of Family Health and Action Research center 2005. Available at: <http/www.bioline.org.br/request?> access on 14/04/ 2018.

${ }^{38} \mathrm{~S}$ Mahdi., (ed) 'Overview and Analysis of Gender Based Violence in Nigeria; January to June 2012'. A publication of Legislative Advocacy Coalition on Violence against Women (LACVAW).

${ }^{39}$ O Izuora., 'Dealing decisively with the issue of Rape'. A Publication in De Abengo (Abuja based) Magazine, 201315.

${ }^{40} \mathrm{M}$ Deuter, et als (Eds.) Advanced Learners Dictionary ( $7^{\text {th }}$ Edition Oxford University Press, 2007) 359.

${ }^{41}$ Oyediran., and Isiugo Abanihe, (n6) 108.
} 
Ujah Marian Ofunu \& Shaba Sampson., Sch Int J Law Crime Justice, Apr, 2021; 4(4): 189-197

encourage abuse [42]. It is a known fact that certain culturally acceptable behaviours, though detrimental to women are championed by women themselves. Women activist are often time perceived wrongly and accused of being meddlesome, jobless and evil, even by the very women whose cause they champion. It would therefore be incongruous to expect any woman who believes that her husband was showing her love [43] by beating her up to support any activist who wants such a man to be punished.

Based on research on women's perception of domestic violence, experts [44] claim that it is evident that approval of wife abuse varies according to the personal attribute of those involved. For example, the high level of agreement for wife beating manifested among the Northern women could be a function of their socio- cultural and economic circumstances which is substantially different from those of southern Nigeria. Southern environment and cultures permit closer conjugal interaction that concedes more freedoms to women. The ethnic differences observed in women's agreement of wife abuse could be explained in terms of the social institution of gender and women's autonomy.

The above illustration supports the notion that an ethnic group that is more gender restrictive is more likely to condition women to agree or consent to wife beating. Generally, Nigerian ethnic groups have strong patriarchal structure, but the Hausa Fulani and Northern minority ethnic groups are more gender restrictive and women from these ethnic groups conceded to wife beating more than their Igbo and Yoruba counterparts, who are also better educated and had more egalitarian conjugal relationships.

\section{Economic}

Women's economic dependence on men as well as limited access to cash and credit; discriminatory laws regarding inheritance; property right; use of communal land and maintenance after divorce or widowhood; limited access to employment in formal and informal sectors; limited access to education and training of women among others constitute impediments to the effectuation of the rights of women against domestic violence.

World Bank reports has it that, "women are more likely than men to work as unpaid family labourers or in the informal sector. Women farmers tend to farm smaller plots and less profitable crops than men, women entrepreneurs operate in smaller farms and less profitable sectors." As a result, some women tend

\footnotetext{
${ }^{42}$ More work need to be done to educate women against the mindset that it is right to be abused.

${ }^{43}$ From Focus Group discussion leading to the British Council Sector report 2013.

${ }^{44} \mathrm{~A}$ Kolawole and O Isiugo Abenihe, 'Women is Health and Action Research Center', 2015.
}

to earn less than men [45]. Consequently, gender gaps in productivity and earnings, for example, are persuasive and they are driven by deep-rooted gender differences.

In a speech at the launching of the World Bank report in Abuja [46], the Former Governor of the Nigerian Central Bank, Mallam Sanusi Lamido Sanusi described how by rewarding long hours at work was depriving women of the opportunity to compete effectively because of their traditional roles in the home. The Banking sector also perpetuates oppression of women in the progression of their banking careers. In addition, Women Rights Advocates notes with sadness the institutionalization of prostitution whereby young girls are encouraged to bring in businesses to the bank at all costs [47].

A portrait of the poor African girl was painted by an activist in the following words; "She is (18.5) eighteen and half years old. She lives in a rural area, she has dropped out of school, she is single, but is about to be married or be given in marriage to a man approximately twice her age. She will be the mother of six or seven kids in another twenty years" [48]. The British Council Gender in Nigerian Report, 2012 situates women at sixty to seventy per cent of the rural work force. It goes further to enumerate other sobering indices of the economic realities that keep Nigerian women dependent and as such exposed to more violence from their stronger and more empowered male counterparts.

In some cases, women earn less than men with lower qualifications. According to a report by the British Council in 2012, women occupy fewer than thirty per cent of all posts in the public sector and only seventeen per cent of senior positions [49]. Moreover, it has been observed that many women do not own bank accounts due to rigorous requirements from financial institutions for identification. From these largely

\footnotetext{
45 'World Bank Development Report 2015, Gender Equality and Development'. A Publication of the World Bank, 2015 24-27.

${ }^{46}$ May 21, 2012 at Sharaton Hotel and Towers Abuja

${ }^{47} \mathrm{O} \mathrm{E}$ Osatohaunwe, 'Inequality in Society and the Impact on Women in E Azinge and L Uche (eds.) Law and Domestic Violence in Nigeria ( Nigeria Institute of Advanced Legal Studies, 2012) .338.

${ }^{48} \mathrm{O}$ Ezekwesili, citing the annual World Bank Publication of 2012, in African Development Indicators (ADI), 2012, available at: $<$ http//web.worldbandk.org/website external/countries/Africa content mole, 22182932-menu pk; 258657-- 2865106 p1pk: 2865128 the site; 258644 , html>. Accessed on 10/5/2019.

${ }^{49}$ The British Council's report on gender in Nigeria, 201223.
} 
Ujah Marian Ofunu \& Shaba Sampson., Sch Int J Law Crime Justice, Apr, 2021; 4(4): 189-197

illiterate women, access to loan facilities is therefore lacking.

The issue of ownership of land is a problem to women in Nigeria. The Land Use Act of 1978 which is currently the Legislation in force in Nigeria vests all land in Nigeria on the State Governor to hold in trust for the citizens. A research conducted by the British Council reveals that, in practice, access to land varies from place to place [50] but largely still subjected to traditional and Islamic Sharia practices. In reality, because of their "inferior" position in the traditional scheme, women's ownership of land is subject to matrilineal considerations. Where an enterprising woman needs land as collateral for growing her business she will either have to depend on her savings or the good will of members of the family and friends. Often times, this brings humiliation upon her and in extreme cases actual violence in the domestic arena.

Another study [51] reported many incidences of property right violations (disinheritance in appropriation of estates) and laments that it appears many people are not aware that such economic violations are indeed violations that should be actionable. According to the study, "women and children who are the common victims of this violation form the crux of the vulnerable and the down trodden in our societies begging their way to survive" [52] in the midst of their male counterparts. Law, being a means of social change can champion the cause of women through relevant reforms to reflect current realities. Where equal rights have been guaranteed by the grund norm of the land, the Judiciary must not shy away from its indispensable role in pronouncing against cultural and religious biases that tend to oppress the women. The Supreme Court's decision in the case of Ukeje $\mathrm{v}$ Ukeje [53], is a radical departure from cultural rites in favour of the women based on constitutional provisions. This is heart-warming and encouraging.

\section{Legal}

Legal factors impede the enforcement of the rights of women against domestic violence. Lesser legal status of women either by written law or by practice; enactment of obnoxious laws regarding divorce, child custody, maintenance and inheritance; amputated legal definition of rape and domestic abuse; insensitive treatment and brutalization of women and girls respectively by the judiciary and the police militate against the realization of women rights.

Nigeria is yet to reform most of the laws inherited from her colonial past and therefore, the

\footnotetext{
${ }^{50}$ Ibid, 34.

${ }^{51}$ Mahdi, (n38) 25-29.

${ }^{52}$ Ibid.

${ }^{53}$ Ukeje v Ukeje, (2014)11 NWLR (1418) 384.
}

nearest provisions that could be called into aid for the victims of domestic violence would be those providing for assault.

Ifemeje asserts that, not only is Nigeria's customary laws fraught with an army of discriminatory practices against women but her indigenous statutory laws also reveal an unfortunate gender bias [54] citing section 55 of the penal code which provides:

Nothing is an offence which does not amount to inflicting of grievous hurt upon any person which is done by a husband for the purpose of correcting his wife being subjected to native law or custom in which such correction is recognized as lawful.

By this provision, a man can flog his wife to correct her, so long as he does not inflict grievous hurt on her. She stated further that rather than condemn this provision which flagrantly dehumanizes women, unfortunately the Court of Appeal in Akinbuwa $v$ Akinbuwa [55] upheld the notion that a man can chastise his wife whereas there is no corresponding provision that exists for similar 'correction' of the man by his wife. Other provisions of Nigerian law which further entrenched gender discrimination and inequality into the legal system are sections 353 and 360 of the Criminal Code.

Section 353 makes indecent assault against a male a felonious offence punishable with three years' imprisonment, while section 360 makes a similar offence of indecent assault on females a mere misdemeanor punishable with a maximum of two years' imprisonment. The discrimination in the terms of imprisonment is not unconnected with the sexes of the affected persons. Section 6 of the Criminal Code by implication expressly legalizes spousal rape when it provides that unlawful carnal knowledge means carnal connection which takes place otherwise than between husband and wife. Section 138 of the Evidence Act also lays the onus on the victim (of rape) to present proof beyond reasonable doubt.

To Okagbue, "the area of private moral is best left to the religious, social and educational influence; and that the state regulation of private morals can only be justified where there is utilitarian justification for intervention beyond the protection of the moral code" [56]. This strict legal approach to law, with respect, creates room for manipulation within traditional/religious customs and practices which then become conveniently protected as private. It was the argument canvassed in his defense when civil society

\footnotetext{
${ }^{54}$ Ifemeje, (n34) 143.

${ }^{55}$ (1998)7 NWLR (pt. 559) 661.

${ }^{56}$ I Okagbue., The Reform of Sexual Offences in the Nigerian Criminal Law (Nigeria Institute of Advanced Legal Studies 1991) 2.
} 
Ujah Marian Ofunu \& Shaba Sampson., Sch Int J Law Crime Justice, Apr, 2021; 4(4): 189-197

took up a case against Nigerian senator [57] whose excuse for marrying an under-aged girl was that it was his religious tenets that entitled him. It was not immediately realized by the general public that the Nigerian senator's marriage to a13 year old Egyptian girl, though contrary Nigerian law was actually permissible by his Islamic faith. Unfortunately, this matter dragged on until it became a waste of precious time to inquire about.

It is however, the primary function of law to proscribe harmful activities and with regards to sexual activity, the law should protect the personal integrity of individuals against sexual violence; the young and other special groups who cannot fully appreciate the notion of sexual activity and may thus be exploited or corrupted; and the society against acts which offend the public against community standard of morality [58].

The tripartite legal system, which entails the use of the statutory legal system, the Customary and Sharia legal systems further compound the legal status of women in Nigeria. The patriarchal Nigerian society readily adopts the legal system which favours the relegation of women. For instance, despite that gender equality is enshrined in the Nigerian Constitution, regional and international instruments, the male dominated society still prefer those discriminatory aspects of the Customary/Sharia laws which adversely affect the status and position of women in the society.

Nigeria is signatory to many International Instruments such as the Convention on the Elimination of all Forms of Discrimination against Women (CEDAW), but is yet to domesticate the provisions of some of these instruments. Furthermore, the effect of the many years' of military misrule has negatively affected the human rights treatments of the citizens of Nigeria and women are particularly the worse hit. In addition, the economic downturn as a result of the mismanagement and corruption of the military governments has impoverished Nigeria, placing it as one of the poorest countries despite her enormous natural and human resources. Nigerian women bear the brunt of poverty and constitute the poorest of the poor in the society [59].

\footnotetext{
${ }^{57}$ A Usman. 'Nigerian Human Rights Groups Claim Senator Ahmed Yerima's Child Bride undermines Protection for Legal Status of Children' available at: <www.theguardian.nig.com>. July13, 2013, accessed on November 202020.

${ }^{58}$ Okagbue, (n24).3.

${ }^{59}$ B Olateru-Olagbegi, and B A Afolabi, 'Actual Women Situation in Nigeria: A Critic on the Legal Framework in Nigeria' [2012] Nigerian Institute of Advanced Legal Studies 83.
}

The problem of enforcement of laws is another obstacle. In the World Development Reports of 2012, the non-effective enforcement of rights of women was blamed on 'low capacity or bias of State institution' [60].

\section{Political}

Political factors impede the rights of women against domestic violence in several ways. Under representation of women in power and polities; the notion of family as private affairs beyond the control of the State; limited organization by women as a political force; and limited participation of women in organized political system are some among the several ways politics hamstrung the rights of women.

In a report by the British Council Gender, 2015 women's participation in governance and politics in Nigeria, rather than improving to meet the goals set in the Nigerian gender policy (NAP) of 2006, is regressing instead. For instance, the 2015 [61] general elections saw a drastic reduction in the number of women in the National and State Assemblies and no woman emerged as governor of any State. Rather than the proposed 35\% Affirmative Act [62] Quota being pushed for, the number of women in the Senate dropped. The representation of women law makers in the various state Houses of Assembly is equally abysmal [63]. What this implies is that at the highest level of political and professional decision making, men are dominant which influences decision making in their favour. The composition of executives of the Nigeria Bar Association through the years has nominal number of elected women [64].

\section{Illiteracy}

Illiteracy is another factor that affects the rights of women with respect to domestic violence. It has been contended that given the impossibility of a Government by all members of a modern complex society, comprising millions of people spread over a large territory, free speech and free press are means by which the society as a collection of individuals can

60 'The World Development Report 2012, Gender Equality and Development', World Bank Publication, 667.

${ }^{61}$ The British Council Gender Report of (2015).53-58.

${ }^{62}$ Principally by civil society. Prominent among them is the First Lady of Nigeria initiative - Women for Change and Development Initiative (WACDI); 100-groups consultative group (B-100) championed by the former Minister of Women Affairs and Social Development, Iyaron Josephine Anenih.

${ }^{63}$ Ibid.

${ }^{64}$ Usually, it is not more than two or three. It is even worse in the branches where often time, one or two women end up with welfare portfolio to serve food and drinks to the more deserving gentlemen. 
Ujah Marian Ofunu \& Shaba Sampson., Sch Int J Law Crime Justice, Apr, 2021; 4(4): 189-197

participate in Government. They are instruments through which the people get informed and educated about the affairs of Government thereby enabling them to form and express intelligent opinions on such matters.

As a corollary to the above, free speech and free press helps in exposing corruption, abuse of office and other wrong doings of public servants such as infringement of human rights by the government. The fact that their conducts and characters are open to public debate in Mass Media may be counted as the greatest check on official misconduct or corruption [65]. It however, appears the above benefits are not maximally utilized due to the very strong reason that greater percentage of Nigerians and particularly women are illiterates. And because they participate less owing to illiteracy they are scarcely carried along when important decisions affecting their wellbeing are taken.

It is important to note that any democracy that does not strive to drastically reduce illiteracy exposes itself to a lot of dangers. This is aptly summarized by Ojo when he said:

Democracy is not safe in a country where a large majority of the population is illiterate. Their inability to understand the problems of government is readily visible. Worse still, they become very strange bed fellows to politician who make extravagant promises [66].

The issue of illiteracy and its negative effects on the populace, particularly as it affects women had also been underpinned by Ake when he said, "Freedom of speech and freedom of the press do not mean much for largely illiterate rural community completely absorbed in the daily rigours of the struggle for survival" [67].

Most Nigerian women are not even aware of their rights under the law as a result of illiteracy. So much need to be done on the education of women with respect to protection laws generally and the orientation

${ }^{65} \mathrm{~T}$ Makinde, 'The Problem of Policy Implementation in Developing Nations: The Nigerian Experience' [2013] (2) (1) Lagos State University of Journal of Political Science 68.

${ }^{66} \mathrm{~J}$ D Ojo, Development of the Executive under the Nigerian Constitution, 1960-1981 (Lagos University Press, 1999) 169.

${ }^{67} \mathrm{C}$ Ake., 'The African Continental Human Rights in African Context', being a paper presented at a conference held at Port Harcourt, from 9-11 of June 1987, cited by J N Aduba, Impediment to the Realization of Fundamental Human Rights in Nigeria: In Human Right Teachings in Schools (Constitution Rights Project, 1999) 120. about how they can seek redress whenever their rights are violated. Positive attitudinal disposition of women is equally key and imperative in this voyage of selfdiscovery, and the realization of the comeliness nature has bestowed on them, and how indispensable they are to any functional and progressive system.

\section{CONCLUSSIONS}

This paper has been able to examine factors that impede the realization of the rights of women against domestic violence. There is the urgent need for the Nigerian Law Reform Commission to review the Violence against Persons (Prohibition) and Other Related Matters Act, 2015 and other laws relating to domestic violence in the various States of the Federation to meet international standards. Customary practices that violate the rights of women against domestic violence need to be repealed as some of them are contrary to natural justice, equity and good conscience. There is also the need to extend the jurisdiction of Magistrate and Customary Courts to accommodate claims by victims of domestic violence in the local areas.

In order to encourage victims of heinous violence, rape and other related cases such should be handled with utmost confidentiality while violators are made to face the wrath of the law.

Law Enforcement Agencies particularly the police force should be reoriented and trained on the best practices in responding to domestic violence especially in investigation, documentation and prosecution.

Women also need to do a rethink on their role as women and mutually complementary to men, but not as competitors. The Civil Societies should intensify their efforts in their campaign against domestic violence bearing in mind that domestic violence is not only against women but against all members of the victim's family.

It is also essential for Nigeria to emulate other jurisdictions like United Kingdom, United States of America, India, South Africa and Turkey, which have domesticated laws that prohibit domestic violence against women. 